\title{
EFEKTIFITAS PEMBELAJARAN JIGSAW PADA MATA PELAJARAN PENDIDIKAN JASMANI DI SMA NEGERI 1 LEIHITU BARAT
}

\author{
Mieke Souisa', Mariana Ditboya Hukubun² \\ 1,2 Dosen Prodi Pendidikan Jasmani Kesehatan dan Rekreasi FKIP Universitas Pattimura \\ Email: ms.souisa1512@gmail.com¹, marianahukubun01@gmail.com² \\ DOI: https://doi.org/10.36526/kejaora.v4i2.701
}

\begin{abstract}
ABSTRAK
Tujuan penelitian ini untuk menganalisis efektifitas pembelajaran jigsaw pada mata pelajaran pendidikan jasmani di SMA Negeri 1 Leihitu Barat. Hal ini bertujuan untuk mendapatkan informasi metode apa yang tepat dalam mata pelajaran pendidikan jasmani di sekolah. Metode Penelitian yang digunakan menggunakan deskriptif kualitatif. Hasil penelitian menunjukkan bahwa; 1) perencanaan materi yang disiapkan sudah sesuai dengan silabus dan RPP, 2) realita proses pembelajaran jigsaw yang dilaksanakan oleh guru, berjalan sesuai dengan perencanaan yang telah disusun sebelumnya, 3) pengalaman belajar yang dilakukan oleh utusan dari masing-masing kelompok belajar sama sekali tidak berjalan sesuai dengan prosedur pembelajaran. Dalam penelitian ini dapat disimpulkan bahwa penggunaan metode jigsaw belum efektif karena guru pendidikan jasmani (penjas) belum memahami dengan baik prosedur pembelajaran jigsaw. Hal ini terbukti dengan pembagian kelompok belajar yang tidak sesuai dengan jumlah materi.
\end{abstract}

Keywords: Jigsaw, pendidikan jasmani (penjas)

\section{PENDAHULUAN}

Guru merupakan faktor penentu yang sangat dominan dalam pendidikan pada umumnya, karena guru memegang peranan penting dalam proses pembelajaran, dimana proses pembelajaran merupakan inti dari pendidikan secara keseluruhan. Proses pembelajaran sendiri merupakan suatu proses yang mengandung serangkaian perbuatan guru dan siswa atas hubungan timbal-balik yang berlangsung dalam situasi edukatif untuk mencapai tujuan tertentu, dimana dalam proses tersebut terkandung multiperan guru.

Salah satu diantara multiperan guru yaitu "dapat mengembangkan potensi anak". Terkait dengan peran dimaksud, maka guru perlu mengetahui potensi anak didik. Karena dengan mengetahui potensi anak didik, guru dapat menyiapkan strategi pembelajaran yang sinerjik, sesuai dengan potensi anak didik.

Sejalan dengan peranan mengembangkan potensi anak didik, maka Rusman (2013) mengategorikan beberapa komponen penunjang terwujudnya peranan dimaksud, antara lain; (1) guru sebagai demonstrator, (2) guru sebagai pengelola kelas, (3) guru sebagai mediator dan fasilitator, dan (4) guru sebagai evaluator. Apabila keempat komponen penunjang tersebut dilaksanakan dengan baik, maka potensi anak didik dapat dikembangkan.

Pendidikan jasmani (penjas) merupakan salah satu mata pelajaran yang memiliki kedudukan sama dengan mata pelajaran lainnya dalam setiap jenjang pendidikan, baik dari jenjang Sekolah Dasar (SD), Sekolah Menengah Pertama (SMP), maupun Sekolah Menengah Atas (SMA). Tentunya juga membutuhkan peran guru yang dapat mengembangkan potensi anak didik, dengan memperhatikan keempat komponen dimaksud.

Pendidikan jasmani sendiri merupakan mata pelajaran yang kompleks. Dalam menjalankan peran untuk mengembangkan potensi anak didik, guru penjas juga dibekali dengan berbagai pengetahuan tentang berbagai strategi, 
pendekatan, metode pembelajaran yang dapat menyukseskan pencapaian tujuan pembelajaran yang telah ditetapkan dalam pembelajaran. Namun dalam menjalankan proses pembelajaran, penggunaan strategi, pendekatan, dan metode, perlu memerhatikan situasi dan kondisi, cirikhas dari materi yang diajarkan, serta kemampuan awal dari siswa. Hal ini merupakan kondisi ideal yang harus diperhatikan untuk dilaksanakan oleh setiap guru penjas agar cikal bakal manusia yang memiliki sumber daya yang berpotensi dapat ditelorkan.

Namun kondisi ini sepertinya belum bisa dimaksimalkan di daerah kita, kondisi untuk menggampangkan tugas dan tanggung jawab seperti halnya mengcopy paste perangkat pembelajaran dari sekolah lain, atau menggunakan perangkat yang jarang direvisi, bahkan jarang sekali menggunakan metode-metode pembelajaran yang menarik perhatian siswa, dibandingkan dengan yang lazim digunakan. Hal-hal tersebut dapat saja terjadi karena beberapa alasan mendasar, salah satu diantaranya mungkin saja guru jarang sekali mengikuti perkembangan pembelajaran yang berhubungan dengan penggunaan dan pengaplikasian pembelajaran yang aktif partisipatif dari siswa, sehingga akan mempengaruhi proses pembelajaran yang berujung pada hasil evaluasi diakhir proses. Tanpa disadari hal tersebut merupakan tindakan yang dapat berdampak pada terhambatnya pengembangan potensi anak didik kita nantinya.

Sekolah Menengah Atas (SMA) Negeri 1 Leihitu Barat, merupakan salah satu sekolah yang berada pada di kabupaten Maluku Tengah Provinsi Maluku. karena letak lokasi sekolah ini jauh dari pusat pemerintah Kabupaten Maluku Tengah, tepatnya Masohi, bisa saja menyebabkan terhambatnya penyampaian informasi-informasi terbaru terkait berbagai inovasi dalam dunia pendidikan. Bukan hanya guru di sekolah ini, bahkan jika kita mau melihat lebih dalam masih ada juga guru penjas yang notabene ada dipusat ibu kota provinsi Maluku, yang masih minim kreatifitas dalam mengembangkan dan mengaplikasikan metode-metode mengajar yang mampu menarik perhatian siswa di sekolah saat proses pembelajaran berlangsung. Sehingga terbesit dalam benak bahwa guru yang ada di pusat kota saja masih banyak yang belum kreatif, bagaimana halnya yang jauh dari pusat perkotaan. Hal ini tentu saja akan berdampak dalam menghambat proses pengembangan potensi anak didik kita kedepan.

Jigsaw merupakan salah satu jenis pembelajaran aktif yang mampu menarik perhatian siswa, mengingat cirikhas pembelajaran ini dimana siswa akan berperan aktif dalam berbagi pengalaman antara teman yang satu dengan teman yang lain, dengan materi yang berbeda-beda, sehingga siswa akan saling memperkaya dengan saling membagi konsep pengetahuannya. Namun akankah pembelajaran jigsaw ini dapat dilaksanakan sesuai dengan prosedur jika dikaitkan dengan permasalahan yang telah dipaparkan sebelumnya?. Sadar akan hal tersebut, maka sebagai akademisi memiliki tanggung jawab untuk mendalami realita yang telah dipaparkan pada bagian sebelumnya.

\section{Faktor-faktor yang Mempengaruhi Pembelajaran \\ Dalam melaksanakan proses} pembelajaran, terdapat faktor-faktor yang turut mempengaruhi proses dan hasil belajar. Sejalan dengan faktor-faktor tersebut, maka Djamarah (2011), mengategorikan faktorfaktor yang mempengaruhi proses dan hasil belajar sebagai berikut; (1) Faktor Lingkungan, terdiri dari; (a) Lingkungan alami, (b) Lingkungan sosial budaya. (2) Faktor Instrumental, terdiri dari; (a) kurikulum, (b) Program. (3) Sarana dan Fasilitas. (4) Guru.

Berdasarkan 5 (lim) faktor diatas, maka uyang akan dibahas pada bagian ini yaitu faktor guru. Seperti yang dikemukakan Djamarah (2011), guru merupakan unsur manusiawi dalam pendidikan. Kehadiran guru mutlak (segalanya) diperlukan di dalamnya. Jika hanya terdapat siswa atau subyek yang dididik tanpa adanya guru, maka proses pembelajaran tidak akan terjadi di sekolah.

Lebih lanjut dikemukakan pula bahwa tidaklah gampang untuk menuntut guru yang profesional, karena semuanya terpulang dari sikap dan mental guru. Guru yang profesional lebih mengedepankan 
kualitas pengajaran daripada materiil oriented, melainkan kualitas kerja lebih diutamakan daripada mengambil mata pelajaran yang bukan bidang keahliannya. Ibarat sebuah ungkapan "tidak ada rotan, akarpun jadi" itulah yang tepat bagi seorang guru profesional, sehingga tidaklah mudah untuk menyerah pada keadaan.

Lebih lanjut dikatakan pula bahwa persoalan guru memamg menyangkut dimensi yang luas, tidak hanya bersentuhan dengan masalah di luar dirinya seperti mampu berhubungan dengan masyarakat di luar sekolah, juga dengan anak didiknya kapan dan dimanapun guru tersebut berada, melainkan juga masalah yang berhubungan dengan diri pribadinya, mampukah seorang guru dapat menjadikan dirinya baik atau tidak? Itulah yang menjadi persoalan utama.

Terkait dengan persoalan utama yang berkaitan dengan pribadi guru untuk bisa membuat dirinya baik atau tidak, maka Soelaeman, 1985 (dalam Djamarah, 2011), mengemukakan bahwa "untuk menjadi guru yang baik tidaklah hanya dengan mengandalkan bagakt ataupun hasrat (emansipasinya) dan lingkungan saja, namun harus disertai dengan kegiatan studi (belajar), dan latihan serta praktek atau pengalaman yang memadai agar muncul sikap guru yang diinginkan, yang dapat melahirkan kegairahan kerja yang menyenangkan."

Sejalan dengan pendapat diatas maka dapat dikatakan bahwa memang untuk dapat mempengaruhi hasil anak didik, guru perlu membekali dirinya dengan berbagai perkembangan ilmu pengetahuan dalam dunia pendidikan, terlebih khusus dalam mengembangkan dirinya untuk menguasai berbagai strategi pembelajaran, sehingga dapat menciptakan pembelajaran yang menyenangkan dan bermanfaat bagi genearsi penerus bangsa dimasa depan.

\section{Hakikat Pembelajaran Jigsaw}

Silberman (2013) mengemukakan dengan jelas bahwa "pembelajaran jigsaw sama dengan pertukaran antar kelompok". Pertukaran kelompok sendiri merupakan pemberian tugas yang berbeda kepada para kelompok peserta. Dengan perbedaan utama antara pertukaran kelompok dan jigsaw yaitu "setiap peserta mengajarkan sesuatu".
Dikemukakan pula bahwa pembelajaran jigsaw ini menarik bila ada materi yang harus dipelajari, yang dapat dibagi menjadi beberapa segmen kecil, dan tidak ada pada bagian segmen tersebut yang harus diajarkan terlebih dahulu dari bagian segmen yang lain. Selanjutnya setiap peserta mempelajari suatu hal, yang jika dikombinasikan dengan materi yang dipelajari oleh peserta lain, maka terbentuklah pengetahuan yang saling berkaitan.

\section{Efektifitas Pembelajaran Jigsaw pada mata pelajaran pendidikan jasmani}

Pada bagian sebelumnya telah dipaparkan dengan rinci bahwa konsep inti dari Pembelajaran jigsaw yaitu, "Pertukaran kelompok" dengan pemberian tugas yang berbeda kepada para kelompok peserta, dmana setiap peserta mengajarkan sesuatu kepada kelompok lainnya, tentang apa yang dipelajari pada kelompok sebelumnya atau kelompok asal.

Sehingga dalam penerapan pembelajaran jigsaw ini, sebenarnya memberikan ruang bagi siswa untuk berusaha untuk mendalami dan memahami tugas yang diemban, dan mampu menjelaskan sesuai konsep dasar tugas tersebut kepada kelompok lain, dimana anggota dari masing-masing kelompok akan saling melebur menjadi satu kelompok, dan saling berbagi pengalaman belajar dengan sesama anggota kelompok baru.

Sementara guru hanya mendampingi dan mengarahkan jalannya proses pembelajaran jigsaw sesuai dengan prosedur yang dikehendaki dalam pembelajaran ini. Terkait dengan konsep jigsaw ini, jika kita kaitkan dengan pembelajaran konvensional, dimana pembelajaran masih terpusat kepada guru, maka siswa tidak akan mengalami langsung pengalaman belajar berupa materi, tetapi siswa hanya berperan untuk mendengar penyampaian dari guru selaku pusat pembelajaran.

Manusia dilahirkan sebagai individu yang memiliki perbedaan antara manusia yang satu dengan manusia yang lainnya. Untuk itu, kemampuan kognisi, psikomotor, dan juga afeksi akan berbeda antara yang satu dengan yang lainnya. Guru sendiri 
memiliki kemampuan atau skill yang berbeda dengan siswa. Dengan demikian, cara penyampaian materi pun akan berbeda bahkan terkadang siswa tidak mampu untuk memahami apa yang disampaikan oleh guru. Sehingga juga turut mempengaruhi penguasaan indikator pembelajaran, juga tujuan pembelajaran yang ditetapkan tidak akan tercapai.

Oleh karenanya, konteks pembelajaran jigsaw, memberikan ruang, kepada siswa secara utuh untuk berperan aktif menyampaikan tugas belajar berupa materi yang telah dipelajari pada kelompok sebelumnya, berdasarkan kemampuan yang dimiliki yang bisa dikatakan kemampuan dan cara berpikir yang masih setara antara siswa yang satu dengan siswa yang lainnya, agar para siswa memahami dengan baik.

\section{METODE}

Untuk mengungkapkan realita pembelajaran jigsaw pada mata pelajaran pendidikan jasmani di sekolah SMA Negeri 1 Leihitu barat, maka metode yang digunakan adalah "kualitatif", dikarenakan peneliti ingin mendalami secara deskriptif tentang situasi pembelajaran jigsaw yang terjadi pada mata pelajaran pendidikan jasmani.

Sehingga untuk bisa mendalami situasional dari subyek dalam penelitian ini, maka peneliti menggunakan desain penelitian "deskriptif kualitatif", seperti pada diagram 2 dibawah ini.

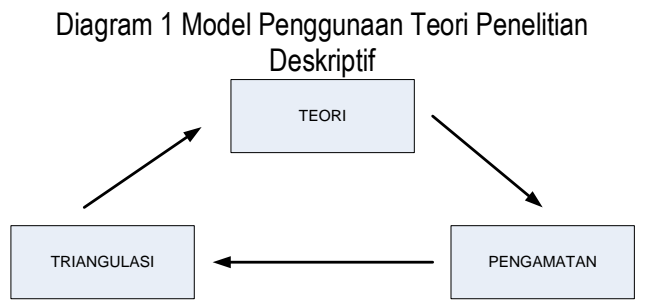

Sumber: Bungin (2014)

\section{Analisis Data}

Untuk menganalisis data dalam penelitian ini, maka peneliti menggunakan analisis data selama dilapangan oleh Miles dan Huberman, 1984 (dalam Sugiyono, 2013), yang terdiri dari; data reduction (reduksi atau pencatatan data), data display (penyajian data), conclusion drawing/verification (penarikan kesimpulan atau verifkasi data) seperti yang dapat dilihat dalam gambar 1 dibawah ini.
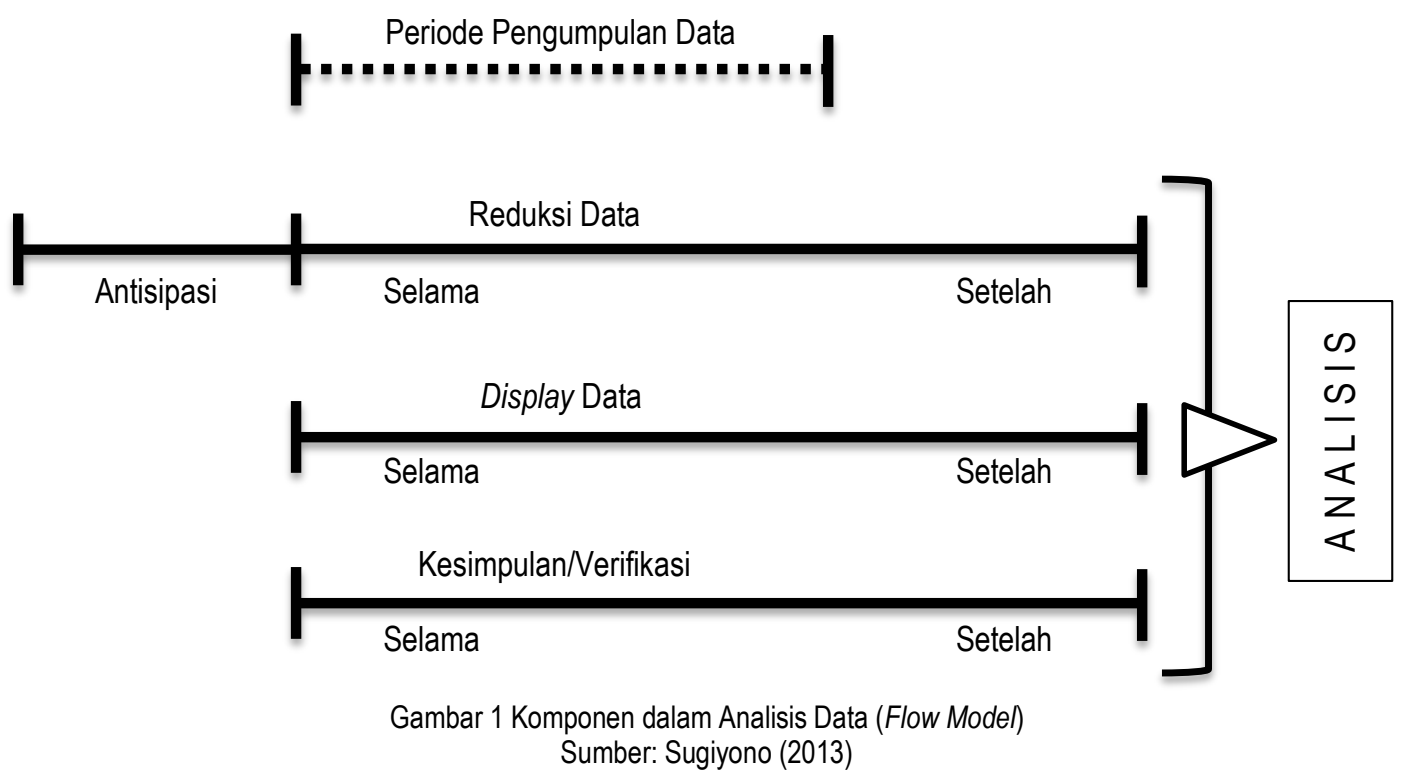

\section{HASIL DAN PEMBAHASAN}

Dari proses pengumpulan data, serta data yang diperoleh di lapangan, dimana ketika pengambilan data dilakukan, pada pertemuan terakhir mata pelajaran pendidikan jasmani, dimana penelitian ini difokuskan pada penggunaan pembelajaran jigsaw pada materi kesehatan, tentang 
penyakit menular HIVIAIDS, maka hasil yang diperoleh tersebut dapat disajikan sebagai berikut:

a. Perencanaan Materi Yang disiapkan guru

Data yang diperoleh sesuai dengan silabus dan Rencana Persiapan Pembelajaran (RPP) memperlihatkan bahwa guru melakukan pembelajaran sesuai dengan perangkat yang telah disusun, diawal semester dengan beberapa data utama bagian perencanaan pembelajaran dengan menggunakan pembelajaran jigsaw

\section{b. Kondisi Real Pelaksanaan Pembelajaran Jigsaw \\ Berdasarkan proses pembelajaran} yang dilaksanakan pada 4 (empat) kelas berbeda di SMA Negeri 1 Leihitu Barat selama 4 (empat) hari, pada masing-masing kelas tersebut diatas, antara lain;

Tabel 1

Realisasi Pengorganisasian Waktu Pelaksanaan Pengumpulan Data di Lapangan

\begin{tabular}{|c|c|c|c|c|c|c|}
\hline \multirow[t]{2}{*}{ No. } & \multirow[t]{2}{*}{ Kegiatan } & \multicolumn{4}{|c|}{ November 2016} & \multirow[t]{2}{*}{ Keterangan } \\
\hline & & 14 & 15 & 16 & 17 & \\
\hline 1. & Pengambilan data kelas $\mathrm{XI} I \mathrm{PA}{ }_{1}$ & $\sqrt{ }$ & & & & Selesai \\
\hline 2. & Pengambilan data kelas XI IPS & & $\sqrt{ }$ & & & Selesai \\
\hline 3. & Pengambilan data kelas $\mathrm{XI} I \mathrm{PA}_{2}$ & & & $\sqrt{ }$ & & Selesai \\
\hline 4. & Pengambilan data kelas XI IPS & & & & $\sqrt{ }$ & Selesai \\
\hline
\end{tabular}

Dengan materi yang sama, mengingat materi tersebut merupakan materi pertemuan terakhir. Untuk itu berdasarkan pelaksanaan proses pembelajaran maka realita proses pembelajaran jigsaw yang dilaksanakan oleh guru, berjalan sesuai dengan perencanaan yang telah disusun sebelumnya.

\section{c. Temuan selama Jalannya Proses Pembelajaran Jigsaw \\ Berdasarkan pembelajaran yang} dilaksanakan, terdapat beberapa yang ditemui, yang merupakan kontradiksi antara kondisi ideal yang seharusnya terjadi dalam pembelajaran jigsaw, dengan kondisi yang sebenarnya dijalankan dalam pembelajaran jigsaw, pada 4 (empat kelas). Hal tersebut antara lain;

1) Kelompok belajar (distribusi kelompok tahap I) dibagi dalam 4 (empat) kelompok besar.

2) Pada kelompok belajar (distribusi tahap I) ini, materi yang dibagikan tidak seimbang, seharusnya, guru membagikan kelompok berdarkan jumlah materi. Sehingga pada kelompok belajar ini kelompok 4 (empat atau kelompok terakhir) mendapat pembagian 2 materi untuk dibahas dalam kelompoknya.

Tentu saja hal ini akan mempersulit pembagian kelompok berikut (pembelajaran kooperatif/distribusi kelompok tahap II), karena akan terjadi ketidak seimbangan anggota kelompok terhadap tugas materi yang harus dijelaskan kepada kelompoknya.

3) Saat siswa didistribusikan lagi ke dalam 5 (lima) kelompok pembelajaran kooperatif (distribusi kelompok tahap II), siswa diarahkan untuk mempelajari kembali materi yang dibagikan sama seperti pada materi sebelumnya kelompok belajar (distribusi tahap I). Selanjutnya masingmasing kelompok mempresentasikan hasil kerja kelompoknya dalam forum diskusi.

Pada tahap ini, seharusnya anggota yang diutus dari kelompok asal (kelompok belajar atau distribusi tahap I) bergabung dengan utusan dari ke-tiga leompok lain, sehingga pada tahap ini masing-masing utusan kelompok akan menjelaskan atau menyampaikan pengalaman belajar yang dilakukan dikelompok asal kepada teman lain dalam kelompok pembelajaran kooperatif ini. Sehingga mereka akan saling memperkaya dalam kelompok pembelajaran kooperatif ini.

Sehingga saat kegiatan membagi pengalaman belajar yang dilakukan oleh utusan dari masing-masing kelompok belajar sama sekali tidak berjalan sesuai dengan prosedur pembelajaran. 
Pembelajaran jigsaw merupakan salah satu pembelajaran yang menarik, karena setiap siswa akan diberikan tanggung jawab atau tugas tanpa terkecuali. Ketika siswa berada dalam kelompok belajarnya, siswa harus bisa mendalaminya agar bisa menyajikan materi yang dipelajari atau didalami kelompok, saat para anggota kelompok belajar dilebur pada kelompok pembelajaran kooperatif. Sehingga dengan pengalaman belajar seperti ini, siswa akan mengalami langsung, bahkan siswa akan termotivasi untuk aktif dalam pembelajaran.

Dari hasil temuan yang diperoleh saat pengumpulan data, maka dapat disampaikan bahwa, guru pendidikan jasmani (penjas) belum memahami dengan baik prosedur pembelajaran jigsaw. Hal ini terbukti dengan pembagian kelompok belajar yang tidak sesuai dengan jumlah materi. Demikian pula pembagian materi untuk dipelajari pada kelompok pembelajaran kooperatif tidak perlu dilakukan, karena pada kelompok pembelajaran kooperatif, semua materi akan dibahas atau disajikan oleh utusan dari masing-masing kelompok belajar.

Kemudian tidak perlu ada diskusi, karena sebenarnya proses diskusi sudah berjalan saat siswa berada pada kelompok pembelajaran kooperatif. Dimana masingmasing utusan akan menyajikan materi dalampok pembelajaran kooperatif tersebut, dan akan terjadi saling menanggapi dalam kelompok dengan tujuan untuk mendapat kejelasan atas materi yang disajikan.

Hal tersebut tidak akan terjadi jika saja guru memahami dengan baik prosedur atau langkah-langkah dalam pembelajaran jigsaw dimaksud. Untuk itu dapat dikatakan bahwa pembelajaran jigsaw jarang digunakan oleh guru penjas. Karena jika pembelajaran ini sering digunakan, maka guru tidak akan keliru dalam menjalankan prosedur pembelajaran jigsaw.

\section{KESIMPULAN}

Dari hasil penelitian, dapat disimpulkan bahwa Guru pendidikan jasmani belum menguasai pembelajaran jigsaw saat mengantarkan atau menyajikan materi. Hal ini dapat dibuktikan dengan beberapa hal, antara lain; a. Pembagian kelompok belajar yang tidak sebanding dengan jumlah materi pembelajaran.

b. Pembagian materi pada kelompok pembelajaran kooperatif untuk didiskusikan tidak perlu dilakukan, karena tidak sejalan dengan prosedur pembagian kelompok pembelajaran kooperatif.

c. Akibat pembagian materi untuk didiskusikan dalam kelompok, berdampak pada timbulnya sistuasi nganggur bagi sebagian anggota kelompok.

d. Diskusi dan saling menanggapi antar kelompok yang tidak perlu terjadi dalam kelompok pembelajaran kooperatif.

e. Berdasarkan beberapa hal tersebut diatas, maka dapat dikatakan bahwa pembelajaran jigsaw jarang digunakan oleh guru penjas. Karena jika pembelajaran ini sering digunakan, maka guru tidak akan keliru dalam menjalankan prosedur pembelajaran jigsaw.

\section{DAFTAR PUSTAKA}

Arikunto, Suharsimi. 2002, Prosedur Penelitian Suatu

PendekatanPraktek. Jakarta: Rineka Cipta.

Arisman. 2002. Gizi Dalam Daur Kehidupan. Palemban : Direktorat Jendral, Pendidikan Tinggi Departemen Pendidikan Nasional.

Arikunto, Suharsimi. 2002, Prosedur Penelitian Suatu PendekatanPraktek. Jakarta : Rineka Cipta.

Arikunto, Suharsimi. 2002. Prosedur Penelitian. Jakarta: Rineka Cipta.

Depdikbud. 1995, Tes Kesegaran Jasmani Indonesia Anak Umur 13-15 Tahun. Jakarta : Pusat Kesegaran Jasmani dan Rekreasi.

Depdiknas. 2010. Tingkat Kesegaran Jasmani. Jakarta: Pusat Kesegaran Jasmani dan Rekreasi.

Djoko Pekik Irianto. (2004). Bugar dan Sehat Dengan Olahraga. Yogyakarta : Andi Offse

Sadoso Sumosardjuno. (1992). Pengetahuan Praktis Kesehatan dan Olahraga.

Jakarta: Pustaka Kartini

Depdiknas. 2010. Tingkat Kesegaran Jasmani. Jakarta: Pusat Kesegaran 
Jasmani dan Rekreasi.

Depdiknas. 2010. Tingkat Kesegaran Jasmani. Jakarta: Pusat Kesegaran Jasmani dan Rekreasi.

Depdiknas, 2000. Pedoman Dan Modul Penelitian Kesehatan Olahraga Bagi Pelatih Olahragawan Pelajar. Depdiknas Pusat Pengembangan Kualitas Jasmani Jakarta.

Djoko Pekik Irianto. (2006). Panduan Gizi Lengkap Keluarga dan Olahragawan.

Yogyakarta: Andi Offset

Faruq, Albertus. 2015, Tes \& Pengukuran Dalam Olahraga. Yogyakarta: Andi Offset. I Dewa Nyoman Supariasa. 2001. Penelitian Status Gizi. Jakarta: KedokteranEGC.

Kamus Umum Bahasa Indonesia, Edisi Ketiga, 2003, Balai Pustaka, Jakarta.

Maryanto, 1993.Pendidikan Olahraga Dan Kesehatan.PT. Yudistira . Jakarta..

Marsetyo dan Kartasapoetra. 1995. IImu Gizi (Korelasi Gizi, Kesehatan danProduktifitas Kerja). Jakarta: Rineka Cipta

Mukholid, Agus. 2004. Pendidikan Jasmani dan Olahraga. Jakarta: Yudistira.

Mukholid, Agus. 2004. Pendidikan Jasmani dan Olahraga. Jakarta: Yudistira

Nurhasan. (2005). Aktivitas Kebugaran. Jakarta: Depdiknas.

Nurharsono,Tri. 2006. Tes Pengukuran Pendidikan Jasmani dan Tes Kesegaran

Jasmani Atlet. Semarang : PJKR FIK UNNES

Roji. 2006. Pendidikan Jasmani Olahraga dan Kesehatan. Erlangga. Jakarta

Pekik, Djoko, 2004, Pedoman Praktis Berolahraga untuk Kebugaran dan Kesehatan, Yogyakarta: Penerbit Andi.

Sajoto, 1988, Pembinaan Kondisi Fisik dalam Olahraga, Jakarta: Departemen Pendidikan dan Kebudayaan Direktorat Jendral Pendidikan Tinggi.

Sumosardjono, Sadoso, 1989. Petunjuk Praktis Kesehatan Olahraga. Jakarta :Pustaka Karya Grafita Utama.
Sutarto, Asmira . 1980. IImu gizi untuk STO. Jakarta: New Ngua Press.

Sumosardjono, Sadoso, 1989. Petunjuk Praktis Kesehatan Olahraga. Jakarta :Pustaka Karya Grafita Utama.

Sutarto, Asmira . 1980. IImu gizi untuk STO. Jakarta: New Ngua Press.

Soekirman, 2006. Hidup Sehat, Gizi Seimbang Dalam Siklus Kehidupan

Manusia, Primamedia Pustaka, Jakarta

Soekirman. 2000. IImu Gizi dan Aplikasi Untuk Keluarga dan Masyarakat.Jakarta: Direktorat Jenderal Pendidikan Tinggi.

Supariasa, I Dewa Nyoman ., 2002. Penelitian Satatus Gizi. Buku Kedokteran EGC Jakarta

Widi Astuti, 2015. Tes dan Pengukuran. Depok: Rajawali Press

WHO (World Health Organization). 2010. Obesity and overweight: programmes and project of global stategy on diet, physical activity an health. Geneva, Switzerland: WHO Document Production Services. Arikunto, Suharsimi. 2002. Prosedur Penelitian. Jakarta: Rineka Cipta.

WHO.World Health Organization.1995. Physical Status:The Use and Interpretation of Antropometry. World Health Organization. Geneva. 